\title{
ANALISIS KEPUTUSAN ORANG TUA SISWA MEMILIH LEMBAGA PENDIDIKAN MELALUI KUALITAS PELAYANAN JASA PENDIDIKAN (STUDI EMPIRIS PADA TAMAN KANAK-KANAK ISLAM DI KELURAHAN CINERE KOTA DEPOK)
}

\author{
Udin Ahidin \\ e-mail: dosen00406@unpam.ac.id
}

\begin{abstract}
ABSTRAK
Tujuan penelitian ini untuk mengetahui kualitas pelayanan lembaga pendidikan Taman Kanak-Kanak Islam di Kelurahan Cinere Kota Depok, untuk mengetahui keputusan orang tua siswa memilih lembaga Pendidikan Taman Kanak-Kanak Islam di Kelurahan Cinere Kota Depok, untuk mengetahui pengaruh kualitas pelayanan terhadap keputusan orang tua siswa memilih lembaga pendidikan Taman Kanak-Kanak Islam di Kelurahan Cinere Kota Depok.

Metode penelitian yang digunakan asosiatif dengan pengujian Hipotesis. Populasi dalam penelitian ini orang tua siswa TK Islam di Kelurahan Cinere Kota Depok sebanyak 920 orang. Sampel yang ditetapkan sebanyak 90 orang. Metode pengumpulan data observasi, studi kepustakaan dan angket. Metode analisis data: Uji Validitas, Uji Reliabilitas, Uji Regresi Linier Sederhana, Uji Korelasi Product Moment, Uji Determinasi, dan Uji Signifikansi (Uji t).

Penelitian ini hasilnya menunjukan bahwa kualitas Pelayanan pada lembaga pendidikan Taman Kanak-Kanak Islam Di Kelurahan Cinere Kota Depok dipersepsikan sangat baik skor rata-rata sebesar 4,66 masuk pada skala interval 4,20-5,00 dengan interpretasi sangat baik. Tingkat keputusan orang tua siswa memilih lembaga pendidikan Taman Kanak-Kanak Islam Di Kelurahan Cinere Kota Depok dipersepsikan sangat tinggi, rata-rata skor keputusan memilih sekolah sebesar 4,68 masuk pada skala interval 4,205,00 dengan interpretasi sangat tinggi. Ada Pengaruh positif kuat dan signifikan antara kualitas pelayanan terhadap keputusan orang tua siswa memilih lembaga pendidikan Taman Kanak-Kanak Islam di Kelurahan Cinere Kota Depok. Hal ini dibuktikan oleh nilai koefesien regresi linier sederhana $Y=8,278+0,803 X$. Nilai Koefesisen Korelasi $r=0,665$. Nilai Koefesien Determinasi KD=44,3\% dan Nilai t hitung $>t$ tabel $(8,360>1,662)$.
\end{abstract}

Kata kunci : Kualitas Pelayanan dan Keputusan Orang Tua Siswa Memilih Lembaga Pendidikan.

\section{ABSTRACT}

The purpose of this study was to determine the quality of service of Islamic kindergarten education institutions in Cinere Village, Depok City, to find out the parents 'decision to choose Islamic Kindergarten Education Institution in Cinere Village, Depok City, to find out the effect of service quality on parents' decisions choose an Islamic kindergarten education institution in Cinere Village, Depok City.

The research method used is associative with hypothesis testing. The population in this study were 920 parents of Islamic kindergarten students in Cinere Village, Depok City. The sample set was 90 respondents. Methods of collecting observation data, literature studies and questionnaires. Data analysis methods used are Validity Test, Reliability Test, Simple Linear Regression Test, Product Moment Correlation Test, Determination Test, and Significance Test (t test).

The results showed that the quality of services at Islamic kindergarten educational institutions in Cinere Village, Depok City was perceived to be very good with an average Vol. 2 No. 2 Februari 2019 
score of 4.66 in the 4.20-5.00 interval scale with very good interpretation. The level of decision of parents choosing Islamic kindergarten education institutions in Cinere Village, Depok City is perceived to be very high, the average score of the decision to choose a school is 4.68 in an interval of 4.20-5.00 with very high interpretation. There is a strong and significant positive influence between service quality on parents' decision to choose Islamic kindergarten education institutions in Cinere Village, Depok City. This is evidenced by the simple linear regression coefficient value $Y=8,278+0,803 X$. Coefesis Value Correlation $r=0,665$. The Coefficient of Determination $K D=44.3 \%$ and the value of $t$ count $>t$ table (8.360> 1.662).

Keywords: Service Quality and Decision of Student Parents Choosing Educational Institutions.

\section{A. Pendahuluan}

Salah satu lembaga pendidikan untuk melakukan pengembangan SDM pemula bagi individu maupun kelompok masyarakat yaitu Sekolah Taman KanakKanak (TK) Islam di Kelurahan Cinere Kota Depok dalam penelitian ini diambil tiga sekolahan yang dijadikan obyek penelitian yaitu TK Islam Al-Kautsar, TK AlKholidin, dan RA Hidayatusshibyan.

Berdasarkan studi pendahuluan yang penulis lakukan di lapangan, didapat fenomena yang menarik untuk diteliti yaitu didapat data penerimaan siswa baru di tiga sekolahan TK tersebut selama 4 (empat) Tahun Ajaran. Data ini merupakan sampel dalam menganalisis awal dari permasalahan yang dihadapi oleh lembaga pendidikan Taman Kanak-Kanak yang dikelola oleh pihak swasta yang ada di Kelurahan Cinere Kota Depok Provinsi Jawa Barat. Data tersebut dapat disajikan sebagai berikut:

Tabel 1.1

Data Penerimaan Siswa Baru Taman Kanak-Kanak Di Kelurahan Cinere Kota Depok

\begin{tabular}{|c|c|c|c|c|c|c|c|}
\hline \multirow[b]{2}{*}{ No } & \multirow[b]{2}{*}{ Nama Sekolah } & \multirow[b]{2}{*}{ Tingkatan } & \multicolumn{4}{|c|}{ Tahun Ajaran } & \multirow[b]{2}{*}{$\begin{array}{c}\text { Jumlah } \\
\text { Total }\end{array}$} \\
\hline & & & $\begin{array}{c}2014- \\
2015\end{array}$ & $\begin{array}{l}2015- \\
2016\end{array}$ & $\begin{array}{r}2016- \\
2017\end{array}$ & $\begin{array}{c}2017- \\
2018\end{array}$ & \\
\hline \multirow[b]{2}{*}{1.} & \multirow{2}{*}{ TK Islam Al-Kautsar } & $A$ & 99 & 56 & 56 & 47 & \multirow{2}{*}{541} \\
\hline & & $\mathrm{B}$ & 73 & 67 & 82 & 61 & \\
\hline \multirow{2}{*}{2.} & \multirow{2}{*}{ TK Al- Kholidin } & A & 9 & 8 & 13 & 16 & \multirow{2}{*}{154} \\
\hline & & $B$ & 31 & 26 & 34 & 17 & \\
\hline \multirow{2}{*}{3.} & \multirow{2}{*}{ RA Hidayatusshibyan } & $\mathrm{A}$ & 14 & 17 & 15 & 17 & \multirow{2}{*}{225} \\
\hline & & $B$ & 53 & 47 & 32 & 30 & \\
\hline
\end{tabular}

Sumber : Hasil Observasi (2018)

Berdasarkan tabel di atas dapat dilihat bahwa terjadi fluktuatif penerimaan jumlah siswa pada TK Islam di Kelurahan Cinere Kota Depok. Hal itu diduga dengan banyaknya jumlah lembaga pendidikan TK di Kelurahan Cinere Kota Depok, salah satunya yang menyebabkan fluktuatif penerimaan murid disekolah TK Islam tersebut dikarenakan banyak pilihan sekolah TK Islam di Cinere sesuai dengan persepsi orang tua murid. Fluktuatifnya jumlah penerimaan siswa baru di TK Islam tersebut merupakan sebuah indikasi bahwa tingkat keputusan memilih sekolah orang tua siswa terjadi fluktuatif juga. 
Di sisi lain didapat fenomena menarik yang disinyalir salah satu faktor penyebab fluktuatifnya tingkat keputusan memilih sekolah orang tua siswa fluktuatif, yaitu tingkat kualitas pelayanan yang masih rendah. Hal itu dapat di lihat dari data empiris hasil observasi (2018) berikut ini:

\section{Tabel 1.2}

Data Tingkat Pendidikan Tenaga Pendidikan (Guru)

\begin{tabular}{|c|l|c|c|}
\hline No. & \multicolumn{1}{|c|}{$\begin{array}{c}\text { Tingkat Pendidikn Tenaga Pendidikan } \\
\text { (Guru) }\end{array}$} & Jumlah & Persentase \\
\hline 1 & S.1 PAUD & 0 & $0 \%$ \\
\hline 2 & S.1 Pendidikan Islam & 7 & $19 \%$ \\
\hline 3 & S.1 Pendidikan Non Islam & 10 & $27 \%$ \\
\hline 4 & S.1 Non Pendidikan & 5 & $14 \%$ \\
\hline 5 & Diploma Pendidikan & 2 & $5 \%$ \\
\hline 6 & Diploma Non Pendidikan & 0 & $0 \%$ \\
\hline 7 & SLTA / Sederajat & 13 & $35 \%$ \\
\hline
\end{tabular}

Sumber : Hasil observasi (2018)

Berdasarkan data pada tabel 1.2 di atas, didapat informasi bahwa jaminan (Assurance) yang merupakan salah satu dimensi kualitas pelayanan Jika dilihat dari tingkat kemampuan guru, maka sekolah PAUD atau TK Islam harus diajar oleh guru S.1 PAUD atau Sarjana Pendidikan Islam (S.Pd,I), sedangkan guru yang lulusan S 1 PAUD tidak ada (0\%), adanya lulusan S.1 Pendidikan Islam dan jumlahnya terbatas hanya 7 orang atau $19 \%$, bahkan lulusan SLTA/sederajat paling banyak sebesar $35 \%$ sudah mengajar. Oleh karena itu kualitas pelayanan pada dimensi jaminan (Assurance) tingkat kemampuan guru masih rendah. Sehingga diduga keputusan pembelian (memilih lembaga pendidikan) orang tua masih rendah disebabkan oleh kualitas pelayanan yang masih rendah.

Melihat dari berbagai permasalahan di atas, penulis akan menganalisinya melalui judul Analisis Keputusan Orang Tua Memilih Lembaga Pendidikan Melalui Kualitas Pelayanan Jasa Pendidikan (Studi Empiris Pada Taman Kanak-Kanak Islam Di Kelurahan Cinere Kota Depok)

\section{B. Perumusan Masalah}

Berdasarkan paparan latar belakang di atas, untuk mencegah terjadinya kerancuan dalam pembahasan, maka perlu diberikan perumusan masalah sebagai berikut :

1. Bagaimana kualitas pelayanan yang diberikan oleh lembaga pendidikan TK Islam di Keluarahan Cinere Kota Depok?

2. Bagaimana keputusan orang tua siswa memilih lembaga pendidikan TK Islam di Keluarahan Cinere Kota Depok ?

3. Apakah terdapat pengaruh kualitas pelayanan terhadap keputusan orang tua siswa memilih lembaga pendidikan TK Islam di Keluarahan Cinere Kota Depok?

\section{Tujuan Penelitian}

Penelitian ini agar fokus dan terarah, maka tujuan penelitian ini:

1. Untuk mengetahui kualitas pelayanan yang diberikan oleh lembaga pendidikan TK Islam di Keluarahan Cinere Kota Depok? 
2. Untuk mengetahui keputusan orang tua siswa memilih lembaga pendidikan TK Islam di Keluarahan Cinere Kota Depok?

3. Untuk mengetahui pengaruh kualitas pelayanan terhadap keputusan orang tua siswa memilih lembaga pendidikan TK Islam di Keluarahan Cinere Kota Depok?

\section{Landasan Teori}

Pandangan tentang konsep kualitas (quality) menurut Sallis (2011:30), bahwa kualitas merupakan suatu hal yang membedakan yang baik dan sebaliknya. Di sisi lain Tjiptono (2008:67) menjelaskan bahwa kualitas adalah cerminan semua dimensi penawaran produk yang menghasilkan manfaat (benefit) bagi pelanggan.

Pendapat di atas diperjelas juga oleh Kotler (2013) kualitas sebagai keseluruhan ciri sifat barang dan jasa yang berpengaruh pada kemampuan memenuhi kebutuhan dan keinginan konsumen. Dengan demikian dapat disimpulkan bahwa kualitas merupakan kondisi dinamis yang berhubungan dengan sifat barang dan jasa yang memenuhi atau melebihi harapan pelanggan.

Di sisi lain Tjiptono (2012:3) menjelaskan bahwa pelayanan adalah melakukan sesuatu untuk orang lain. Sebagai jasa, services umumnya mencerminkan produk tidak berwujud fisik (intangible) atau sektor industri spesifik, seperti pendidikan, kesehatan, telekomunikasi, transportasi, asuransi, perbankan, perhotelan, kontruksi, perdagangan, rekreasi, dan sebagainya. Pelayanan adalah segala sesuatu yang dilakukan pihak tertentu (individu maupun kelompok) kepada pihak lain (individu atau Kelompok) misalnya layanan pelanggan (customer service).

"Keputusan pembelian merupakan proses pengintegrasian yang mengkombinasikan pengetahuan untuk mengevaluasi dua atau lebih perilaku alternatif dan memilih salah satu diantaranya" (Peter dan Olson ,2009)

"Beberapa tahapan yang dilakukan oleh konsumen sebelum melakukan keputusan pembelian suatu produk. Konsumen akan memutuskan produk yang akan dibeli berdasarkan presepsi mereka terhadap produk tersebut berkaitan dengan kemampuan produk tersebut dalam memenuhi kebutuhannya" (Kotler dan Keller, 2013)

Menurut Sugiyono (2013), menjelaskan bahwa kerngka berfikir yang baik akan menjelaskan secara teoritis pertautan antar variabel yang akan diteliti. Jadi secara teoritis perlu dijelaskan hubungan antar variabel independen dan dependen. Bila dalam penelitian ada variabel moderator dan intervening, maka juga perlu dijelaskan, mengapa variabel itu ikut dilibatkan dalam penelitian. Pertautan antar variabel tersebut, selanjutnya dirumuskan ke dalam bentuk paradigma penelitian. Oleh karena itu pada setiap penyusunan paradigma penelitian harus didasarkan pada kerangka berfikir.

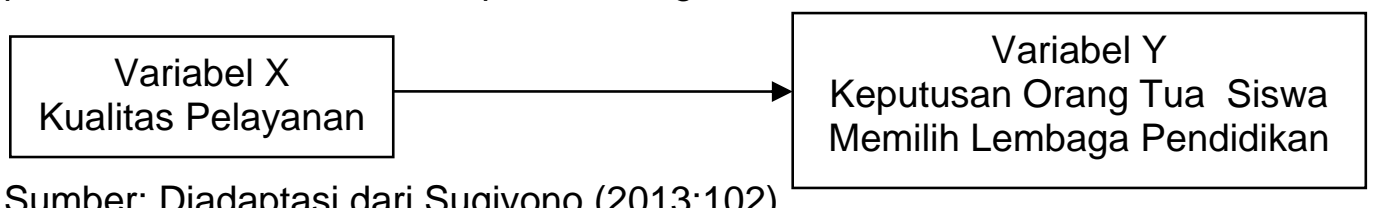

Sumber: Diadaptasi dari Sugiyono (2013:102)

Gambar 1.1

Model Paradigma Penelitian 


\section{E. Metodologi Penelitian}

Objek dalam penelitian ini TK Islam yang ada di Kelurahan Cinere Kota Depok. Populasi penelitian ini seluruh orang tua siswa TK Islam di Kelurahan Cinere Kota Depok sebanyak 920 orang periode Tahun Ajaran 2014-2015 sampai dengan 2017-2018. Sampel dalam penelitian ini sebanyak 90 responden. Metode pengumpulan data dalam penelitian ini observasi dan kuesioner. Skala yang digunakan skala likert dan skala interval. Metode analisis data uji validitas, uji reliabilitas, regresi linier sederhana, uji korelasi product moment, uji determinasi, dan uji signifikansi (uji t).

\section{F. Hasil dan Pembahasan}

Hasil Uji Validitas Variabel Kualitas Pelayanan

Tabel 1.3

Hasil Uji Validitas Variabel Kualitas Pelayanan

\begin{tabular}{|c|c|c|c|c|}
\hline Variabel & Indikator & $\mathbf{r}_{\text {hitung }}$ & $\mathbf{r}_{\text {tabel }}$ & $\begin{array}{c}\text { Hasil } \\
\text { keputusan }\end{array}$ \\
\hline \multirow{4}{*}{\begin{tabular}{c} 
Kualitas \\
\cline { 1 - 4 } $\begin{array}{c}\text { Pelayanan } \\
\text { (X) }\end{array}$
\end{tabular}} & X1 & 0,755 & 0,1745 & Valid \\
\cline { 2 - 5 } & $\mathrm{X} 2$ & 0,666 & 0,1745 & Valid \\
\cline { 2 - 5 } & $\mathrm{X} 3$ & 0,838 & 0,1745 & Valid \\
\cline { 2 - 5 } & $\mathrm{X} 5$ & 0,770 & 0,1745 & Valid \\
\cline { 2 - 5 } & $\mathrm{X} 6$ & 0,441 & 0,1745 & Valid \\
\cline { 2 - 5 } & $\mathrm{X} 8$ & 0,663 & 0,1745 & Valid \\
\cline { 2 - 5 } & $\mathrm{X} 9$ & 0,753 & 0,1745 & Valid \\
\cline { 2 - 5 } & $\mathrm{X} 10$ & 0,782 & 0,1745 & Valid \\
\hline
\end{tabular}

Sumber : Hasil pengolahan data SPSS 23.00 (2018)

Informasi dari tabel $1.3 \mathrm{di}$ atas dapat dilihat hasil uji validitas variabel kualitas pelayanan, nilai ini kemudian dibandingkan dengan $r_{\text {tabel, }}$ yang dicari pada signifikasi 0,10 dengan uji 2 sisi dan jumlah sampel $(n)=90$ dengan $\mathrm{df}=$ $n-2$, maka didapat $r_{\text {tabel }}$ sebesar 0,1745. Secara keseluruhan nilai $r_{\text {hitung }}>r_{\text {tabel, }}$ maka dapat disimpulkan bahwa semua butir instrumen pernyataan tersebut valid.

\section{Hasil Uji Validitas Variabel Keputusan Memilih Sekolah}

Tabel 1.4

Hasil Uji Validitas Variabel Keputusan Memilih Lembaga Pendidikan

\begin{tabular}{|c|c|c|l|c|}
\hline Variabel & Indikator & $\mathbf{R}_{\text {hitung }}$ & $\mathbf{R}_{\text {tabel }}$ & $\begin{array}{c}\text { Hasil } \\
\text { Keputusan }\end{array}$ \\
\hline \multirow{4}{*}{\begin{tabular}{c} 
Keputusan \\
memilih \\
sekolah \\
\cline { 2 - 5 }
\end{tabular}} & $\mathrm{Y} 1$ & 0,752 & 0,1745 & Valid \\
\cline { 2 - 5 } & $\mathrm{Y} 2$ & 0,831 & 0,1745 & Valid \\
\cline { 2 - 5 } & $\mathrm{Y} 3$ & 0,738 & 0,1745 & Valid \\
\cline { 2 - 5 } & $\mathrm{Y} 4$ & 0,778 & 0,1745 & Valid \\
\cline { 2 - 5 } & $\mathrm{Y} 6$ & 0,823 & 0,1745 & Valid \\
\cline { 2 - 5 } & $\mathrm{Y} 7$ & 0,741 & 0,1745 & Valid \\
\cline { 2 - 5 } & $\mathrm{Y} 8$ & 0,808 & 0,1745 & Valid \\
\hline
\end{tabular}




\begin{tabular}{|c|c|c|l|l|}
\hline & Y9 & 0,824 & 0,1745 & Valid \\
\cline { 2 - 5 } & Y10 & 0,869 & 0,1745 & Valid \\
\hline
\end{tabular}

Sumber: Hasil pengolahan data SPSS 23.00 (2018)

Informasi dari tabel $1.4 \mathrm{di}$ atas dapat dilihat hasil uji validitas variabel keputusan memilih sekolah, nilai ini kemudian dibandingkan dengan $r_{\text {tabel, }}$ yang dicari pada signifikasi 0,10 dengan uji 2 sisi dan jumlah sampel $(n)=90$ dengan $\mathrm{df}=\mathrm{n}-2$, maka didapat $r_{\text {tabel }}$ sebesar 0,1745 . Secara keseluruhan nilai $r_{\text {hitung }}>$ $r_{\text {tabel, }}$ maka dapat disimpulkan bahwa semua butir instrumen pernyataan tersebut valid.

Hasil Uji Reliabilitas

Tabel 1.5

Hasil Uji Reliabilitas Kualitas Pelayanan dan Keputusan Memilih Sekolah

\begin{tabular}{|c|l|c|c|c|}
\hline No & \multicolumn{1}{|c|}{ Variabel } & $\mathbf{r}_{\text {hitung }}$ & $\mathbf{r}_{\text {kritis }}$ & Keterangan \\
\hline 1 & Kualitas Pelayanan & 0.896 & 0,6 & Reliabel \\
\hline 2 & $\begin{array}{l}\text { Keputusan Memilih } \\
\text { Lembaga Pendidikan }\end{array}$ & 0.925 & 0,6 & Reliabel \\
\hline
\end{tabular}

Sumber: Data di olah dengan SPSS 23.00 (2018)

Informasi dari tabel 1.5 di atas, bahwa pernyataan koesioner variabel kualitas pelayanan dan keputusan memilih lembaga pendidikan memiliki nilai $r_{\text {hitung }}>r_{\text {kritis, }}$ maka dinyatakan reliabel.

Hasil Analisis Data Statistik Deskriptif

1.1. Variabel Kualitas Pelayanan

Tabel 1.6

Distribusi Jawaban Variabel Kualitas Pelayanan

\begin{tabular}{|c|c|c|c|c|c|c|c|c|c|}
\hline \multirow{2}{*}{ No } & \multirow{2}{*}{ PERNYATAAN } & SB & B & CB & TB & STB & \multirow{2}{*}{$\begin{array}{l}\text { Skor } \\
\text { Tota } \\
\text { I }\end{array}$} & \multirow{2}{*}{$\begin{array}{l}\text { Rata } \\
\text {-rata } \\
\text { Skor }\end{array}$} & \multirow{2}{*}{$\begin{array}{c}\text { Ketera } \\
\text { ngan }\end{array}$} \\
\hline & & 5 & 4 & 3 & 2 & 1 & & & \\
\hline & $\begin{array}{r}\text { Kehandalan } \\
\text { (Reliability) }\end{array}$ & & & & & & & & \\
\hline 1 & $\begin{array}{l}\text { Pelaksanaan kegiatan } \\
\text { belajar mengajar sesuai } \\
\text { dengan jadwal yang di } \\
\text { tetapkan }\end{array}$ & 59 & 31 & 0 & 0 & 0 & 419 & 4.66 & $\begin{array}{l}\text { Sangat } \\
\text { Baik }\end{array}$ \\
\hline \multirow[t]{2}{*}{2} & $\begin{array}{l}\text { Pendidikan yang } \\
\text { diberikan kepada siswa } \\
\text { sesuai bidang } \\
\text { keagamaan }\end{array}$ & 58 & 30 & 2 & 0 & 0 & 416 & 4.62 & $\begin{array}{c}\text { Sangat } \\
\text { Baik }\end{array}$ \\
\hline & $\begin{array}{c}\text { Daya Tanggap } \\
\text { (Responsiveness) }\end{array}$ & & & & & & & & \\
\hline 3 & $\begin{array}{l}\text { Guru dan karyawan } \\
\text { bereaksi cepat } \\
\text { memberikan solusi } \\
\text { terhadap siswa dan }\end{array}$ & 49 & 29 & 12 & 0 & 0 & 397 & 4,41 & $\begin{array}{l}\text { Sangat } \\
\text { Baik }\end{array}$ \\
\hline
\end{tabular}




\begin{tabular}{|c|c|c|c|c|c|c|c|c|c|}
\hline \multirow{2}{*}{ No } & \multirow{2}{*}{ PERNYATAAN } & SB & B & CB & TB & STB & \multirow{2}{*}{$\begin{array}{l}\text { Skor } \\
\text { Tota } \\
\text { I }\end{array}$} & \multirow{2}{*}{$\begin{array}{l}\text { Rata } \\
\text {-rata } \\
\text { Skor }\end{array}$} & \multirow{2}{*}{$\begin{array}{c}\text { Ketera } \\
\text { ngan }\end{array}$} \\
\hline & & 5 & 4 & 3 & 2 & 1 & & & \\
\hline & $\begin{array}{l}\text { orang tua jika ada } \\
\text { kendala }\end{array}$ & & & & & & & & \\
\hline \multirow[t]{2}{*}{4} & $\begin{array}{l}\text { Guru dan karyawan siap } \\
\text { menolong siswa dalam } \\
\text { kesulitan }\end{array}$ & 53 & 27 & 10 & 0 & 0 & 403 & 4.48 & $\begin{array}{l}\text { Sangat } \\
\text { Baik }\end{array}$ \\
\hline & Jaminan (Assurance) & & & & & & & & \\
\hline 5 & $\begin{array}{l}\text { Kemampuan guru } \\
\text { sebagai tenaga pendidik } \\
\text { sesuai dengan } \\
\text { bidangnya }\end{array}$ & 38 & 42 & 10 & 0 & 0 & 388 & 4,31 & $\begin{array}{l}\text { Sangat } \\
\text { Baik }\end{array}$ \\
\hline \multirow[t]{2}{*}{6} & $\begin{array}{l}\text { Guru dan Karyawan } \\
\text { melayani siswa dengan } \\
\text { baik dan sopan }\end{array}$ & 58 & 31 & 1 & 0 & 0 & 417 & 4.63 & $\begin{array}{c}\text { Sangat } \\
\text { Baik }\end{array}$ \\
\hline & Perhatian (Emphaty) & & & & & & & & \\
\hline 7 & $\begin{array}{l}\text { Guru dan Karyawan } \\
\text { memahami kebutuhan } \\
\text { dan keinginan siswa dan } \\
\text { orang tua siswa }\end{array}$ & 43 & 39 & 7 & 1 & 0 & 394 & 4,38 & $\begin{array}{c}\text { Sangat } \\
\text { Baik }\end{array}$ \\
\hline \multirow[t]{2}{*}{8} & $\begin{array}{l}\text { Guru memberikan } \\
\text { perhatian kepada setiap } \\
\text { siswa }\end{array}$ & 56 & 31 & 3 & 0 & 0 & 413 & 4.59 & $\begin{array}{c}\text { Sangat } \\
\text { Baik }\end{array}$ \\
\hline & Bukti fisik (Tangible) & & & & & & & & \\
\hline 9 & $\begin{array}{l}\text { Sarana dan prasarana } \\
\text { yang lengkap }\end{array}$ & 38 & 34 & 15 & 3 & 0 & 377 & 4,19 & Baik \\
\hline \multirow[t]{2}{*}{10} & $\begin{array}{l}\text { Desain Bangunan } \\
\text { menarik bertemakan } \\
\text { anak-anak yang islami }\end{array}$ & 35 & 35 & 17 & 3 & 0 & 372 & 4,13 & Baik \\
\hline & JUMLAH & $\begin{array}{c}48 \\
7\end{array}$ & $\begin{array}{c}32 \\
9\end{array}$ & 77 & 7 & 0 & 3996 & 4,44 & $\begin{array}{l}\text { Sangat } \\
\text { Baik }\end{array}$ \\
\hline
\end{tabular}

Sumber : Data diolah 2018

Berdasarkan analisis data pada tabel 1.6 di atas, rata-rata skor variabel kualitas pelayanan sebesar 4,44 masuk pada skala interval interval 4,20-5,00 dengan interpretasi sangat baik. Artinya responden mempunyai persepsi bahwa kualitas pelayanan yang diberikan lembaga pendidikan TK islam di Kelurahan Cinere Kota Depok sangat baik.

\section{Variabel Keputusan Orang Tua Memilih lembaga Pendidikan}


Tabel 1.7

Distribusi Jawaban Variabel Keputusan Orang Tua Memilih Lembaga Pendidikan

\begin{tabular}{|c|c|c|c|c|c|c|c|c|c|}
\hline \multirow[b]{2}{*}{ No } & \multirow{2}{*}{ PERNYATAAN } & ST & $\mathbf{T}$ & CT & $\mathbf{R}$ & SR & \multirow{2}{*}{$\begin{array}{l}\text { Skor } \\
\text { Total }\end{array}$} & \multirow{2}{*}{$\begin{array}{l}\text { Rata- } \\
\text { rata } \\
\text { Skor }\end{array}$} & \multirow{2}{*}{$\begin{array}{c}\text { Ketera } \\
\text { ngan }\end{array}$} \\
\hline & & 5 & 4 & 3 & 2 & 1 & & & \\
\hline & $\begin{array}{l}\text { Pengenalan } \\
\text { Kebutuhan }\end{array}$ & & & & & & & & \\
\hline 1 & $\begin{array}{l}\text { Kami ingin } \\
\text { mendapatkan } \\
\text { pendidikan sekaligus } \\
\text { ilmu agama bagi } \\
\text { anak kami yang } \\
\text { menjadi prioritas di } \\
\text { Sekolah }\end{array}$ & 67 & 13 & 10 & 0 & 0 & 417 & 4,63 & $\begin{array}{l}\text { Sangat } \\
\text { Tinggi }\end{array}$ \\
\hline \multirow[t]{2}{*}{2} & $\begin{array}{l}\text { Kami ingin mencari } \\
\text { sekolah swasta yang } \\
\text { terjangkau }\end{array}$ & 52 & 25 & 11 & 2 & 0 & 397 & 4,41 & $\begin{array}{l}\text { Sangat } \\
\text { Tinggi }\end{array}$ \\
\hline & Pencarian Informasi & & & & & & & & \\
\hline 3 & $\begin{array}{l}\text { Kami mendapatkan } \\
\text { informasi dari media } \\
\text { masa }\end{array}$ & 21 & 41 & 24 & 2 & 2 & 347 & 3,86 & Tinggi \\
\hline \multirow[t]{2}{*}{4} & $\begin{array}{l}\text { Kami mengetahui } \\
\text { sekolah dari orang } \\
\text { terdekat }\end{array}$ & 47 & 32 & 9 & 0 & 2 & 392 & 4,36 & $\begin{array}{l}\text { Sangat } \\
\text { Tinggi }\end{array}$ \\
\hline & Evaluasi Alternatif & & & & & & & & \\
\hline 5 & $\begin{array}{l}\text { Biaya yang } \\
\text { ditawarkan lebih } \\
\text { terjangkau }\end{array}$ & 39 & 31 & 20 & 0 & 0 & 379 & 4,21 & $\begin{array}{l}\text { Sangat } \\
\text { Tinggi }\end{array}$ \\
\hline \multirow[t]{2}{*}{6} & $\begin{array}{l}\text { Lokasi sekolah yang } \\
\text { mudah dijangkau } \\
\text { oleh kendaraan } \\
\text { umum }\end{array}$ & 53 & 27 & 10 & 0 & 0 & 403 & 4.48 & $\begin{array}{l}\text { Sangat } \\
\text { Tinggi }\end{array}$ \\
\hline & $\begin{array}{l}\text { Keputusan } \\
\text { Pembelian } \\
\end{array}$ & & & & & & & & \\
\hline 7 & $\begin{array}{l}\text { Kami milih sekolah } \\
\text { karena menawarkan } \\
\text { pendidikan yang } \\
\text { memprioritaskan } \\
\text { agama }\end{array}$ & 63 & 25 & 2 & 0 & 0 & 421 & 4.68 & $\begin{array}{l}\text { Sangat } \\
\text { Tinggi }\end{array}$ \\
\hline \multirow[t]{2}{*}{8} & $\begin{array}{l}\text { Kami memilih sekolah } \\
\text { untuk anak-anak agar } \\
\text { cerdas dan } \\
\text { berprestasi }\end{array}$ & 58 & 27 & 5 & 0 & 0 & 413 & 4.59 & $\begin{array}{l}\text { Sangat } \\
\text { Tinggi }\end{array}$ \\
\hline & $\begin{array}{c}\text { Perilaku Pasca } \\
\text { Pembelian }\end{array}$ & & & & & & & & \\
\hline 9 & $\begin{array}{l}\text { Kami akan } \\
\text { menyekolahkan } \\
\text { anak-anak kami dari } \\
\text { kakaknya sampai ke } \\
\text { adik-adiknya }\end{array}$ & 50 & 25 & 15 & 0 & 0 & 395 & 4,39 & $\begin{array}{l}\text { Sangat } \\
\text { Tinggi }\end{array}$ \\
\hline
\end{tabular}

Vol. 2 No. 2 Februari 2019 


\begin{tabular}{|c|c|c|c|c|c|c|c|c|c|}
\hline \multirow{2}{*}{ No } & \multirow{2}{*}{ PERNYATAAN } & ST & $T$ & CT & $\mathbf{R}$ & SR & \multirow{2}{*}{$\begin{array}{l}\text { Skor } \\
\text { Total }\end{array}$} & \multirow{2}{*}{$\begin{array}{c}\text { Rata- } \\
\text { rata } \\
\text { Skor }\end{array}$} & \multirow{2}{*}{$\begin{array}{c}\text { Ketera } \\
\text { ngan }\end{array}$} \\
\hline & & 5 & 4 & 3 & 2 & 1 & & & \\
\hline 10 & $\begin{array}{l}\text { Kami akan } \\
\text { merekomendasikan } \\
\text { sekolah ke pihak lain } \\
\text { (teman atau } \\
\text { keluarga) }\end{array}$ & 45 & 30 & 13 & 2 & 0 & 388 & 4,31 & $\begin{array}{l}\text { Sangat } \\
\text { Tinggi }\end{array}$ \\
\hline & JUMLAH & 495 & 276 & 119 & 6 & 4 & 3952 & 4,39 & $\begin{array}{l}\text { Sangat } \\
\text { Tinggi }\end{array}$ \\
\hline
\end{tabular}

Sumber : Data diolah 2018

Berdasarkan data tabel 1.7 di atas, rata-rata skor keputusan orang tua memilih lembaga pendidikan sebesar 4,39 masuk pada skala interval 4,20-5,00 dengan interpretasi sangat tinggi. Artinya responden mempunyai persepsi bahwa keputusan orang tua siswa dalam memeilih lembaga pendidikan TK islam di Kelurahan Cinere sangat tinggi.

Hasil Analisis Data Statistik Inferensia

Hasil Uji Regresi Linear Sederhana

Tabel 1.8

Hasil Uji Regresi Linier sedehana

Coefficients $^{a}$

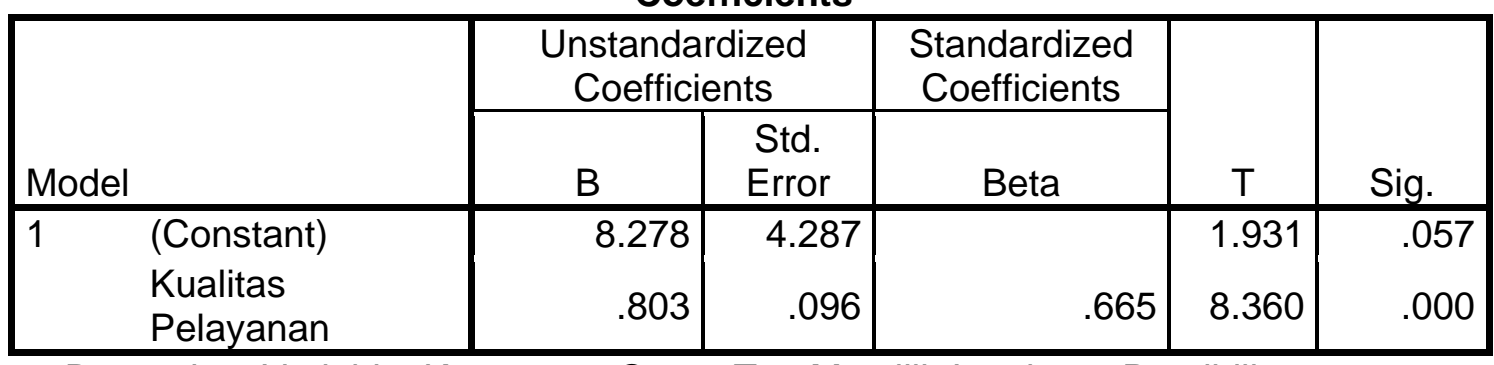

a. Dependent Variable: Keputusan Orang Tua Memilih Lembaga Pendidikan Sumber: Hasil Pengolahan Data SPSS 23.00 (2018)

Informasi dari tabel 1.8 di atas, untuk mencari persamaan regresi linier sederhana dilihat pada kolom 'B'. Konstanta (Constant) adalah 8,278, nilai koefisien regresi linier sederhana $(0,803)$. Sehingga apabila dituliskan, persamaan regresi linier sederhana dari penelitian ini adalah :

$$
Y=8,278+0,803 X
$$

Kesimpulannya bahwa terdapat pengaruh positif antara kualitas pelayanan terhadap keputusan orang tua memeilih lembaga pendidikan TK Islam di Kelurahan Cinere Kota Depok. 


\section{Hasil Uji Korelasi Product Moment}

Tabel 1.9

Hasil Uji Koefisien Korelasi

Correlations

\begin{tabular}{|ll|r|r|}
\hline & \multicolumn{1}{|c|}{$\begin{array}{c}\text { Kualitas } \\
\text { Pelayanan }\end{array}$} & $\begin{array}{c}\text { Keputusan } \\
\text { Pembelian }\end{array}$ \\
\hline Kualitas Pelayanan & Pearson & 1 & $.665^{\star *}$ \\
& Correlation & & .000 \\
& Sig. (2-tailed) & 90 & 90 \\
& $\mathrm{~N}$ & $.665^{\star *}$ & 1 \\
\hline Keputusan & Pearson & .000 & \\
Pembelian & Correlation & 90 & 90 \\
& Sig. (2-tailed) & $\mathrm{N}$ & \\
& $\mathrm{N}$ & & \\
\end{tabular}

${ }^{* \star}$. Correlation is significant at the 0.01 level (2-tailed).

Sumber : Hasil pengolahan data SPSS 23.00 (2018)

Berdasarkan data tabel 1.9 di atas bahwa variabel kualitas Pelayanan dengan Keputusan orang tua memilih lembaga pendidikan memperoleh koefesien korelasi 0,665 masuk kedalam hubungan yang kuat.

\section{Hasil Uji Determinasi}

Tabel 1.10

Hasil Uji Determinasi (R/KD) Model Summary

\begin{tabular}{|l|l|r|r|c|}
\hline Model & $\mathrm{R}$ & $\mathrm{R}$ Square & $\begin{array}{c}\text { Adjusted R } \\
\text { Square }\end{array}$ & $\begin{array}{c}\text { Std. Error of the } \\
\text { Estimate }\end{array}$ \\
\hline 1 & $.665^{\mathrm{a}}$ & .443 & .436 & 4.301 \\
\hline
\end{tabular}

a. Predictors: (Constant), Kualitas Pelayanan

Sumber : Hasil pengolahan data SPSS 23.00 (2018)

Berdasarkan data tabel 1.10 bahwa nilai $R$ Square 0,443 mengandung pengertian variasi perubahan naik turunnya Keputusan orang tua memilih lembaga pendidikan dapat dijelaskan oleh kualitas pelayanan sebesar $44,3 \%$, sementara sisanya yaitu sebesar $55,7 \%$ disebabkan oleh variabel lain.

\section{Hasil Uji Signifikansi (Uji t)}


Tabel 1.11

Uji Signifikan (Hasil Uji t) Coefficients $^{\mathrm{a}}$

\begin{tabular}{|c|c|c|c|c|c|}
\hline \multirow[b]{2}{*}{ Model } & \multicolumn{2}{|c|}{$\begin{array}{c}\text { Unstandardized } \\
\text { Coefficients }\end{array}$} & \multirow{2}{*}{$\begin{array}{c}\begin{array}{c}\text { Standardize } \\
\mathrm{d} \\
\text { Coefficients }\end{array} \\
\text { Beta }\end{array}$} & \multirow[b]{2}{*}{ I } & \multirow[b]{2}{*}{ Sig. } \\
\hline & $B$ & Std. Error & & & \\
\hline (Constant) & 8.278 & 4.287 & & 1.931 & .057 \\
\hline $\begin{array}{l}\text { Kualitas } \\
\text { Pelayanan }\end{array}$ & .803 & .096 & .665 & 8.360 & .000 \\
\hline
\end{tabular}

a. Dependent Variable: Keputusan Pembelian

Sumber : Hasil pengolahan data SPSS 23.00 (2018)

Hasil uji t pada tabel 1.11 bahwa kualitas pelayanan memiliki nilai signifikasi (Sig.) 0,000 pada tabel Coefficients dengan nilai derajat signifikasi 0,10 maka $0,000<0,10$, atau dengan melihat thitung variabel kualitas pelayanan $(X)$ yaitu sebesar 8,360 sedangkan tabel bernilai 1,662 maka 8,360 > 1,662 sehingga Ho ditolak $\mathrm{H}_{1}$ diterima. Dapat diartikan Kualitas pelayanan berpengaruh signifikan terhadap keputusan orang tua memilih lembaga pendidikan TK Islam di Kelurahan Cinere Kota Depok.

\section{G. Kesimpulan}

1. Kualitas Pelayanan pada lembaga pendidikan Taman Kanak-Kanak Islam di Kelurahan Cinere Kota Depok dipersepsikan sangat baik oleh responden. dibuktikan dengan skor rata-rata variabel kualitas pelayanan sebesar 4,66 masuk pada skala interval 4,20 - 5,00 dengan interpretasi sangat baik. Artinya kualitas pelayanan jasa pendidikan TK Islam menurut responden secara ratarata masih sangat baik.

2. Tingkat keputusan orang tua memilih lembaga pendidikan Taman Kanak-Kanak Islam di Kelurahan Cinere Kota Depok dipersepsikan sangat tinggi, dibuktikan dengan rata-rata skor variabel keputusan memilih lembaga pendidikan sebesar 4,68 masuk pada skala interval 4,20 - 5,00 dengan interpretasi sangat tinggi. Artinya keputusan memilih lembaga pendidikan menurut responden secara rata-rata masih sangat tinggi.

3. Terdapat Pengaruh positif kuat dan signifikan antara kualitas pelayanan terhadap Keputusan Orang Tua memilih lembaga pendidikan Taman KanakKanak Islam di Kelurahan Cinere Kota Depok. Hal ini dibuktikan oleh nilai koefisien regresi linier sederhana $Y=8,278+0,803 X$. Nilai Koefisisen Korelasi $r=0,665$. Nilai Koefisien determinasi $K D=44,3 \%$, sisanya yaitu sebesar $55,7 \%$ disebabkan oleh variabel lain. .Nilai t hitung $>t$ tabel $(8,360>1,662)$.

\section{H. Daftar Pustaka}

Angelova Biljana \& Jusuf Zekiri. (2011). Measuring Customer Satisfaction with Service Quality, Trust, and Customer Satisfaction on Customers Loyalty. Abac Journal Vol. 29, No. 1,pp. 24-38.

Isriana Nur Hajjah, Johan Rina Selva,, dan Riadi RM. (2017). Pengaruh Kualitas Pelayanan dan Promosi Terhadap Pengambilan Keputusan Konsumen 
dalam Memilih Sekolah di SD Islam As-Shofa, Universitas Riau. ISSN: 2337-7887.

Kotler Philip \& Gary Amstrong. (2013). Principles Of Marketing, Eisi 5 England: Pearson Education Limited.

Kotler Philip \& Kevin Lane Keller. (2013). Marketing Management, England: Pearson Horizon.

Peter dan Olson. (2009) "Business \& Economics" Jakarta: Raja Grafindo Persada.

Sallis Edward. (2011). Total Quality Management In Education, Manajemen Mutu Terpadu Pendidikan. Alih Bahasa Ahmad Ali Riyadi. Jogjakarta: IRCiSoD.

Schiffman Leon \& Leslie Lazar Kanuk \& Joseph Wisenblit. (2010). Consumer Behavior Tenth Edition, New York: Pearson.

(2008). Perilaku Konsumen. Edisi Ketujuh. Alih Bahasa Zoelkifli Kasip. Jakarta: PT. Indexs.

Siow Natalia. (2013). Kualitas Pelayanan dan Kepercayaan Pengaruhnya Terhadap Keputusan Pembelian Sepeda Motor Suzuki Satria FU 150 Di Kota Manado. Jurnal EMBA Vol. 3, September 2013, Hal.1069-1078.

Sugiyono. (2013). Metode Penelitian Bisnis. Cetakan 17, Penerbit CV Alfabeta, Bandung.

Syafitri Anggia. (20017). Pengaruh kualitas pelayanan, biaya, lokasi, dan promosi terhadap keputusan mahasiswa dalam memilih Fakultas Ekonomi Universitas Musi Rawas.. Jurnal Motivasi. Vol. 2, No. 1

Tjiptono Fandy. (2008). Pemasaran Strategik. Yogyakarta, Penerbit CV Andi Offset. . (2012). Service Management Mewujudkan Layanan Prima. Yogyakarta: CV Andi Offset

.Umar Husein. (2010). Riset pemasaran dan bisnis. Gramedia Pustaka Utama, Jakarta. 